\title{
Lessons from the Making of the MDGs: Human Development Meets Results-based Management in an Unfair World
}

\author{
David Hulme*
}

\begin{abstract}
This article argues that two ideas - human development and results-based management - were particularly significant in shaping the MDGs. These are unlikely intellectual bedfellows, but by charting the evolution of the MDGs, their many influences are demonstrated. The conclusion identifies three main lessons. First, it argues that the MDGs have had only limited impact on policies and actions because the idea behind them, human development, was never fully institutionalised. Second, the article points out the disjuncture that occurred with global goals, the MDGs being operationalised by country level Poverty Reduction Strategies (PRSs) overseen by the International Monetary Fund (IMF) and the World Bank. PRSs need to be genuinely owned by countries, and the IMF and World Bank need to introduce internal 'Arrogance Reduction Strategies' to transform their control-oriented cultures. Finally, the conclusion questions whether the idea of human development is past its 'sell-by' date - do we need a new idea to mobilise and guide post-2015 pro-poor policy?
\end{abstract}

\begin{abstract}
1 Introduction
The Millennium Development Goals (MDGs) are the world's biggest promise - a global agreement to reduce poverty and human deprivation at historically unprecedented rates through collaborative multilateral action. They differ from all other global promises for poverty reduction in their comprehensive nature and the systematic efforts taken to specify, finance, implement, monitor and advocate them.
\end{abstract}

While many different ideas have influenced the 'final' form and content of the MDGs ${ }^{1}$ two specific ideas - human development and results-based management - are identified as having particular significance. However, the ways in which these ideas influenced the evolution of the MDGs has been mediated by many different political interests.

Human development ${ }^{2}$ has become a central idea in international development since the early 1990s. It posits that human beings are the ends as well as the means of development, challenging the focus of many economists and policymakers on per capita economic growth. It has encouraged a focus on the poor and poorest and the prioritisation of capability enhancing services (such as food security, primary education and basic health). It justifies a multidimensional conceptualisation of human wellbeing and poverty, although there are heated debates about the exact dimensions of human development. The works of Paul Streeten et al. (1981), Mahbub ul Haq (1995) and Amartya Sen (1999) are seen as seminal to this concept. The United Nations Development Programme (UNDP) Human Development Reports have been highly effective in mobilising a constituency promoting human development.

Results-based management (RBM), ${ }^{3}$ or performance management, has been central to efforts to improve public service delivery since the 1980s and was highlighted in Osborne and Gaebler's (1992) influential book Reinventing Government. RBM is a 'strategy aimed at 
achieving important changes in the way government agencies operate with improving performance (achieving better results) as the central orientation ... a key component is the process of objectively measuring how well an agency is meeting its stated goals or objectives' (Binnendijk 2001: 3). This encourages a focus on identifying and continuously monitoring Goals, Targets and Indicators. These should be SMART, i.e. specific, measurable, agreed, realistic and time-limited. This focus on 'measurables' leads to a reduced interest in difficult-to-measure goals, such as human rights, participation and democracy.

This article provides a rapid chronological account of the processes that created the MDGs and an analysis using a framework that explores the ways in which ideas, institutions and material capabilities (economic and military power) interact when global policy is being formulated and implemented. ${ }^{4}$ The main objective of the article is to deepen the understanding of the complex ways in which ideas and interests have interacted to shape the form and content of the MDGs and draw lessons from this experience about what should happen after 2015. The conclusion identifies three main lessons. First, it argues that the MDGs have had only limited impact on policies and actions because the idea behind them, human development, was never fully institutionalised. Human development fell between two stools: it did not lead to the emergence of a mass social movement for poverty eradication nor did it create an elite epistemic community that could gain control of the policy agenda. Second, the article points out the disjuncture that occurred with global goals, the MDGs being operationalised by country level Poverty Reduction Strategies (PRSs) overseen by the International Monetary Fund (IMF) and the World Bank. PRSs need to be genuinely owned by countries and the IMF and World Bank need to introduce internal 'Arrogance Reduction Strategies' to transform their control-oriented cultures. Finally, the conclusion questions whether we need a new idea to mobilise and guide post-2015 pro-poor policy?

\section{A brief history of the MDGs: ${ }^{5}$ phase 1 - antecedents and UN summits}

The idea of a dramatic attempt to eradicate or reduce global poverty has antecedents that go back to the mid-twentieth century: the Universal
Declaration of Human Rights (UDHR); the Development Decade of the 1960s; the many UN summits of the second half of the twentieth century; and, books, reports and associated advocacy exercises on the issue (e.g. Galbraith 1979; Myrdal 1970). While the UDHR and some of the UN goal-setting exercises (Jolly 2003) have fostered concerted action, most of these initiatives did not move much beyond the aspiration stage. Around 1980, the idea of a concerted multilateral effort at global poverty reduction stalled, with the arrival of Reagan and Thatcher and the intellectual ascendancy of neoliberal ideas.

By 1990, this climate had changed and the year marked a watershed in the evolution of ideas about international development and poverty reduction. Against the backdrop of the end of the Cold War it saw the World Bank's World Development Report 1990 acknowledge the need for economic reform to be accompanied by social policies (especially primary education for girls). Even more significantly, the first of the UNDP's Human Development Reports was published. This made the idea of human development accessible to a wider group of professionals and to the serious media and gave social activists a relatively coherent (and non-socialist) framework from which to argue for policy change. Around this time what Thérien (1999) calls the 'UN paradigm' began to take on a clearer form, strongly influenced by human development thinking. Rather than simply criticising the Washington Consensus (Thérien's 'Bretton Woods Institutions paradigm') the UN increasingly began to articulate an alternative approach.

The 1990s also saw a number of UN summits, to which the processes leading to the MDGs can be traced. The 'Children's Summit' in New York in 1990, masterminded by Jim Grant of UNICEF, is often seen as the origin of the MDGs. The peak year for UN summitry was 1995, with the World Summit for Social Development in Copenhagen and the UN Fourth World Conference on Women, held in Beijing. The Social Summit was crucial for the MDGs as a global consensus was reached that poverty eradication was the priority for development (UNDP 1997: 108). It approved the target of eradicating extreme income poverty (\$1-a-day poverty as it came to be known) by 2015 and reaffirmed the agreements reached at the Children's Summit of 1990 and the 
reproductive health goals of the 1994

International Conference on Population and Development. Implicitly it drew on the idea of human development and viewed poverty as being multidimensional. The agreement at Copenhagen had particular legitimacy as 117 heads of state and government attended it - the largest meeting of 'heads' there had ever been. ${ }^{6}$ In the same year, the women's summit at Beijing reaffirmed the goals of gender equality and women's empowerment. However, the energy and drive of that summit, with its visions of empowerment and promoting social and economic equality, were not matched by its impact on global agenda setting (Eyben 2006).

UN summits continued in the latter half of the 1990 s, but the location for global goal setting shifted to Paris. This was not part of any grand plan. It was just that in Paris, there was a group of aid agencies needing a set of global goals to tackle their organisational problems - even if they did not yet know this.

\section{A brief history of the MDGs: phase 2 - from summits to lists}

In the mid-1990s most aid agencies had a big problem. Their budgets were being reduced and the total level of official development assistance was in long-term decline. For the donor club, the Organisation for Economic Co-operation and Development's (OECD's) Development Assistance Committee (DAC), these were deep problems. At the DAC high level meeting of May 1995 it was decided to establish a Groupe de Reflexion to review the future of development aid. Early on, the Groupe asked DAC staff to compile a list of UN summit declarations and unexpectedly, this listing became a focus for the Groupe.

Assembling lists of targets had become a common device in the public services of OECD members, as their governments had adopted RBM.

In May 1996, the DAC launched Shaping the 21st Century: The Contribution of Development Co-operation (DAC 1996). This was 20 pages long, but attention focused on its seven 'International Development Goals' (IDGs). ${ }^{7}$ These were a selective and adapted list that reflected OECD interests, and particularly the interests of the OECD's bilateral aid agencies. Unsurprisingly, they were headed by a target for reducing income poverty, on the assumption that economic growth was indispensable for poverty reduction. However, they also included five 'social development' goals (universal primary education, gender equality, reduced infant mortality, reduced maternal mortality and reproductive health for all) which can be seen as a rough attempt to put the idea of human development into practical action. The UN paradigm was making progress. The IDGs were endorsed at several OECD ministerial meetings and by the G7 in 1996, 1997 and 1998 (Bradford 2002: 5). However, in many of the OECD member countries the document did not appear to have much political traction. The 'likeminded' group of progressive donors (Denmark, the Netherlands, Norway and Sweden) took the agreement seriously - indeed, literally - but they were already pursuing IDG-type policies. They had only limited leverage over more powerful donors (the USA, Japan, the UK and France) and multilateral institutions.

In developing countries, the IDGs had little or no resonance. The responses of the major multilaterals varied. For the UN, the report and the IDGs had significance. While it was pleased to see UN declarations re-affirmed, it did not want to lose control of the processes that set the global agenda. In time, it would produce alternative lists (see below). The IDGs registered in several parts of the World Bank, especially the Poverty Unit of the Poverty Reduction and Economic Management Network, but barely registered at the IMF. The responses of nongovernmental organisations (NGOs) varied, but for more radical NGOs and the emerging networks of anti-capitalist and anti-globalisation groups, the IDGs were just rhetoric - platitudes helping capitalism to mask its dependence on the exploitation of labour and the environment.

\section{A brief history of the MDGs: phase 3 - the UN returns to centre stage}

In 1998, the UN re-entered the game of global target setting through planning the Millennium Assembly of the United Nations, to be held at New York in September 2000. The new Secretary-General, Kofi Annan, was keen to make global poverty reduction central to the UN agenda and avoid being simply driven along by security and emergency issues as had happened to his predecessors (Traub 2006: 147).

Countries, international agencies, NGOs, networks and activists energetically began trying to shape the content of the Millennium Assembly 
and Declaration. For the UN, the Millennium Assembly had to be successful. The UN's 50th Anniversary Summit in 1997 was widely regarded as a wasted opportunity. This time, it was felt, there must be an ambitious agenda, and no attention-diverting disagreements should distract the media coverage. Annan appointed a senior adviser, John Ruggie, to draft a preSummit report. This report would be the basis for a final round of negotiations to agree the Millennium Declaration.

The report (Annan 2000) was launched on 3 April 2000, and titled We the Peoples: The Role of the United Nations in the 21st Century. Poverty eradication was its leading issue. However, it had a somewhat different set of poverty reduction goals than the IDGs. A comparison of the goals prioritised in We the Peoples and those in DAC's Shaping the 21st Century reveals that a number of goals do not appear or are watered down (the 'losers'). Others appear on Annan's listing but not in the DAC listing (the 'winners'). There are three big losers: gender equality and women's empowerment; reproductive health; and goals for the health sector. Arguably, the 'winners' were economic growth; technology; the setting of goals for the rich countries; the environment; and highlighting Africa's problems (see Hulme 2009a for a detailed discussion). While there are many differences between the IDGs and We the Peoples, one overarching difference merits particular attention: the goals identified in We the Peoples had less of a human development focus than the IDGs. The 'capabilities' of child survival, maternal survival, reproductive health and gender equality were much less evident.

We the Peoples provided a strong indication of the most progressive agreement that Annan and his advisers thought the Millennium Summit could reach. But Annan also needed to find a way of demonstrating that the UN was coordinating its global poverty reduction efforts with the other big players - the World Bank, IMF and the OECD's bilateral agencies. To this end, in June 2000, the leaders of the four major development multilaterals launched A Better World for All: Progress Towards the International Development Goals (BWFA) (IMF et al. 2000). This document reiterated the DAC's 1996 IDGs almost exactly and strongly re-affirmed the primacy of RBM thinking (IMF et al. 2000: 2-3). Most significantly, the goals in $B W F A$ included reproductive rights and reduced child and maternal mortality - human development goals that We the Peoples had omitted. Beyond its content, BWFA revealed an important aspect of the process of global poverty reduction goal setting - it was a twin track process. The OECD, with its vast resources, was continuing with its IDGs, while the UN, a multilateral institution with greater legitimacy but few resources, was mounting a similar exercise to produce a list from the Millennium Summit. ${ }^{8}$

Over summer 2000, there were frantic negotiations about what should finally go into the Millennium Declaration. The additions, deletions, repositioning of items and compromises that were agreed over these months worked - the Millennium Declaration was unanimously approved by 189 member states (and 147 national leaders) at the UN General Assembly on 8 September 2000. The next formal stage of the process was for the Secretary-General to draw up a 'road map' showing how the world would achieve global poverty reduction.

\section{A brief history of the MDGs: phase 4 - from New York to Monterrey}

Before Kofi Annan could unveil his implementation plan for global poverty reduction, two tasks had to be completed. One was relatively technical: converting the Millennium Declaration text into specific goals and concrete targets. The second was highly political: negotiating a deal with the OECD and its members, so that they would agree to put aside their IDGs. If this was not done then there was the danger of the world having two sets of poverty reduction goals - the OECD's IDG's and the UN's MDGs. The issue came to a head at a World Bank-convened meeting in March 2001 (see Hulme 2009a for an extended discussion). This agreed that a task force of experts from the DAC, World Bank, IMF, and UNDP would finalise the goals.

It is clear from the "final' ${ }^{\text {9 }}$ form of the MDGs that the IDGs, as presented in BWFA (IMF et al. 2000), were taken as the primary document. The reasons for this have never been publicly explained, but there are clear logical grounds related to the arguments and evidence in this article:

The IDGs were relatively coherent from a human development perspective. The goals in the Declaration lacked such coherence. 
- The IDGs were already structured in RBM format - a short, clear list of measurables and the OECD members wanted such a format to ensure that the increased aid they were being pushed to provide would be used to pursue aims they prioritised.

- The most powerful forces in these negotiations, economically and politically (the OECD's members) and technically (the IMF and World Bank), favoured the IDGs. While the development paradigm preferred by the Bretton Woods Institutions could not be publicly resurrected, these organisations ensured that the MDGs fully recognised the centrality of income growth to poverty reduction and that the variant of human development the MDGs pursued was based on a basic needs approach and not human rights or reduced inequality.

Nevertheless, the negotiations had substance and the IDGs were significantly amended. The biggest loss, from a human development perspective, was reproductive health. It was an explicit goal in the IDGs, but the UN could not entertain this because of the objections of a small part of its membership (see Hulme 2009b). The Millennium Declaration did lead to one major addition to the IDG listing: the inclusion of Goal 8, a Global Partnership for Development. Developing countries were not going to accept a set of goals in a UN document that applied only to them. There had to be a goal indicating what the rich world would contribute to global poverty reduction efforts. However, there was a qualitative difference between Goals 1-7 and Goal 8 concerning quantitative targets and dates for achievement, to which we will return below.

In his first Millennium Summit follow-up report of 6 September 2001, titled We the Peoples: The Role of the United Nations in the 21st Century (Annan 2001), Kofi Annan was at last able to unveil the MDGs. Most UN members subsequently started to refer to these goals and many used them as part of their policy and planning processes. The main exceptions to this were the $\mathrm{USA}^{10}$ and India.

Over the year following the Millennium Summit, prospects for a concerted push on global poverty reduction weakened. In part this was inevitable: the Millennium fever that had fuelled progress was over. More significant was the change of US President. Power now rested with a Republican
President guided by a small group of neoconservative advisers, who were very suspicious, perhaps more accurately dismissive, of the UN and foreign aid. This was highly inauspicious for the approaching UN Conference on

International Financing for Development (FFD), now delayed until March 2002. This was where agreement was to be reached on how the extra US $\$ 50$ billion the Zedillo Commission estimated was needed for the MDGs to be achieved would be raised. It seemed likely that President Bush would not attend the FFD conference and possible that the USA might detach itself from the MDG process.

Two factors helped change this. First, in its initial response to the 9/11 attacks, the Bush administration thought a little more than it had previously about 'soft power' approaches to foreign policy. It showed interest in the role of US foreign aid as an adjunct to the 'war on terror'. Second, the FFD conference was in Monterrey and the Mexican President, Vicente Fox, was convenor. President Bush had already declared that Mexico was the USA's most important foreign partner and talked about his close personal relationship with Fox. This put pressure on him to accept the invitation to Monterrey from his friend. As discussed in Mallaby (2004), other factors (a meeting with Bono, lobbying from Christian conservatives, Condoleezza Rice outmanoeuvring Treasury Secretary O’Neill) also encouraged Bush to attend - and once he arrived there, he had to show his generosity. ${ }^{11}$

So, while the commitments made at Monterrey were well below the levels the Zedillo

Commission had identified, and many rich countries had caveats around their aid, trade and debt reforms, overall the FFD conference was seen as a success. The MDGs were informally approved there (but not formally ratified), President Bush committed the USA to being part of the mega-project for global poverty reduction that the MDGs represented and the Monterrey Consensus was forged. On paper at least, global poverty reduction was now a high priority for all countries and international institutions.

\section{The ideas behind the MDGs}

Human development and RBM come from two very different intellectual traditions. Yet both played leading ideational roles in the complex 
and sprawling processes that produced the MDGs. Their forms of influence differed greatly, however. RBM was applied to the MDGs in a very direct fashion. At times Goals, Targets and Indicators were screened for how 'SMART' (specific, measurable, agreed, realistic and timebound) they were. Panels of statistical experts were convened to specify Targets and Indicators and judgements made on RBM principles impacted directly on MDG form and content. By contrast, human development had a much more diffuse influence. It contributed indirectly to the thinking of many of those involved in the processes leading to the MDGs but there is no evidence that the idea was applied directly. ${ }^{12}$

While the idea of human development provided an intellectual guide for UN conferences and associated declarations, it promoted two specific theoretical strands that became underpinnings of the MDGs. First, it advanced the case that development strategies needed to directly pursue the goals of development, and not just the means. Human development provided an overarching conceptual framework for arguing that education and health improvements and gender equality were not only good in their own right but were essential components for the pursuit of a dynamic vision of development. The multidimensional nature of the human development approach created synergy in the interactions between each of these goals. For example, educating children increased their future productivity and income and reduced future infant mortality rates. This would lead to reduced fertility levels and permit women to participate more fully in the market, further raising household incomes. It was a virtuous circle.

Second, when the convenors of the Social Summit, the DAC and the UN drew up lists of goals, they could explicitly or implicitly argue that a list was needed as development and poverty reduction were multidimensional - growth was not enough. Lists of goals were not mere 'shopping lists' reflecting a failure to analyse problems and select priorities (a criticism that had partly undermined 'basic needs' in the 1980s). Rather, a list of multiple goals was essential for any serious development effort based on rigorous thinking.

While the processes behind the placing of items on such lists involved complex interactions involving ideas, empirical evidence, political interests and personal values - human development provided a well-reasoned case for multidimensional lists. In the background were the works of Nobel Laureate Amartya Sen melding economics with philosophy to argue for the promotion of capabilities. His name, along with others, could be cited in an iconic fashion to show that a deep theoretical foundation lay behind such lists.

However, the power of ideas was only part of what was shaping agreements. Interests, articulated by the more economically powerful countries and by international institutions, social movements and the business sector, moderated the influence of human development on the MDGs. At the DAC, delegates realised that a multidimensional list made it easier to enlist the support of issue-based NGOs for increased foreign aid. Having education, gender, health, HIV/AIDS and environmental goals meant that specialist NGOs - those concerned with children, gender, HIV/AIDS, family planning, water, and conservation - would find one of their organisational objectives on the list. So, having a multidimensional list was not only logical it also had political advantages. More negatively, the human development case for reproductive health was challenged by an 'unholy alliance' of the Vatican and conservative Islamic states, which managed to get $\mathrm{G} 77^{13}$ support for their initiative. Consequently, the reproductive health goal disappeared during the negotiations to finalise the MDGs.

The ideational adjunct to human development was results-based management. In the 1990s RBM was on the ascendancy in Business and Management Schools and in the pronouncements of politicians and senior public servants, especially in the rich world. Its commonsense nature and linearity made it attractive - set targets, monitor achievement and reward staff on the basis of performance. It was adopted across the public sector in Australia, Canada, Germany, New Zealand, the UK and the USA and in the systems of many development agencies (e.g. CIDA, DFID, GTZ, NORAD, UNICEF and USAID). ${ }^{14}$ For the aid-financed programmes of the DAC and UN, it was particularly attractive. The widely reported underperformance of aid in earlier years, it could be argued, would not occur in the future as RBM methods would ensure high levels of performance. 
RBM and particularly its tenet of SMART measures influenced the MDGs in three main ways. First, it determined the structure of the MDGs and explains why they are a nested hierarchy of Goals, Targets and Indicators focused on time-bound 'outcomes'. Second, it shaped the specification of goals. While determining exactly what is 'achievable' is not an exact science, one sees this tenet in operation with the $\$ 1$-a-day poverty target. At the UN Summit in Copenhagen, this was set as 'eradicating' extreme poverty by 2015 . When the DAC applied its RBM thinking to this target it was reduced to the more realistic 'halving' extreme poverty by 2015 as DAC statisticians pointed out that 'eradication' would require poverty reduction at rates vastly above anything found in the historical record. Third, the idea of RBM meant that the MDGs avoided potentially difficult-to-measure goals like human rights and participation - such goals were a concern for economically emerging countries in Asia and especially China. These issues could be placed in the introductions and conclusions of key documents, but not in the lists that are to guide plans of action. As a result, the variety of human development that impacted on the MDGs was more a conceptualisation of basic needs than of human rights or of social justice.

As with human development, political interests moderated the full application of RBM. This is most obvious for Goal 8, on 'Developing a Global Partnership for Development', which set out what the rich world would do to assist the fight against poverty. The idea of RBM was rigorously pursued for Goals 1-6 and partially applied to Goal 7. However, it was systematically avoided for Goal 8. While the like-minded group of Northern European social democracies might be willing to agree to 0.7 per cent of GDP to be provided in aid by 2015 (they had already achieved this), the USA, Japan and other rich nations were certainly not going to agree to that (Fukuda-Parr 2006). When powerful countries or groups of countries or interest groups felt threatened by what might be agreed, power relations took precedence over ideas.

Perhaps it was to avoid moving into such political terrain that those engaged in finalising the MDGs neglected to specify the level at which the MDGs were to be monitored - an important element of any robust attempt to apply RBM thinking. This is the topic of the next section as it provides important lessons about the design of future goals and the processes of accountability that surround them.

\section{Monitoring the MDGs and public accountability}

While there is much technical and policy debate among professionals about the findings of UN and World Bank MDG monitoring reports, in theory this data should be part of broader political processes of public accountability. If goals and targets are on track then accountability processes should provide positive feedback to those engaged in global poverty reduction. Conversely, if goals are not being achieved, then accountability processes should test whether these targets are reasonable and, if they are, should put pressure on governments, multilateral agencies and their leaders to perform better. International accountability processes are always complex and this is particularly the case when a vast number of autonomous agents are producing a public good such as global poverty reduction. Assessing the contribution, or lack of contribution, of each agent to the goal, and relating that to goal achievement, may appear virtually impossible. The accountability issue has played out in many ways over the MDGs but of particular significance from an RBM perspective is the level at which monitoring and accountability occur.

Should the MDGs be monitored purely at the global level or is the main focus on the country level? The UN's Millennium Project, and particularly its Director Jeffrey Sachs, has argued that the MDGs are 'country goals', since (1) in a world of sovereign states their operationalisation has to be at the country level, and (2) they '... need to be applied at the country level so governments can be held accountable for signing on to them' (UN Millennium Project 2005: 3). Sachs is particularly concerned that high levels of achievement in China and India would mean that global targets are met while progress in other parts of the world is negligible. Implicitly, Sachs does not trust the governments of many, perhaps most, countries to set their own goals. He has publicly railed against the USA, and to a lesser degree other rich countries, not meeting targets, but he is probably equally suspicious of many poor country governments. However, in attempting to demand country level accountability for global goals is he contesting the concept of national sovereignty, and could 
this particularly undermine the sovereignty of poor countries and the right of their citizens to demand national government accountability?

Jan Vandemoortele (2007) and other colleagues in the UN believe that those who wish to monitor the MDGs at country level - such as Sachs - have 'misunderstood' the goals. He argues that the MDGs were set for the global level from analysing historical global trends and were never intended to be applied to countries or regions. Vandemoortele is particularly concerned that this would lead to reporting that identifies countries as being 'poor performers', despite the fact that economic and social conditions in those countries are getting better. He believes that this will both disempower national governments and undermine public support if MDG failures are reported when indicators are improving. What is needed at the country level is a country-led process of defining national poverty reduction goals based on the trajectories of MDG-type indicators for that specific country, and the development of a plan to meet those targets through a series of intermediate targets (probably every three years). In this way, poverty reduction becomes part of the national political agenda and could be directly linked to national budgets. In effect, Vandemoortele sees the global MDGs as a device for mobilising rich country commitment to poverty eradication, and national level targets as the device for getting national governments to take action against poverty.

In practice, accountability for poverty reduction has been lacking at both the global and the national levels. The UN General Assembly can agree global goals for poverty reduction but it lacks the authority to hold member states accountable for their contributions and achievements. Even in the most extreme and clear situation, with Robert Mugabe and the ZANU-PF government actively creating poverty in Zimbabwe for almost a decade, the UN has proved virtually powerless. If the $\mathrm{UN}$, and other associations of states, can do nothing about a government that by all the objectively verifiable indicators has driven millions of its people into poverty what could it do about a leader or government that was moderately 'off track'? Vandemoortele's proposal for a genuinely national level accountability process is more feasible, in a world of sovereign states and in terms of relating actions to results, but it assumes that states are operating democratically and that poverty reduction is genuinely a major political issue. Unfortunately, these assumptions appear to be rarely valid. ${ }^{15}$ In most low-income countries, PRSs have not set explicit goals, so accountability is diffuse, and PRSs and/or poverty have not become an issue on the domestic political agenda. Instead, poverty targets and plans have tended to be documents produced to keep international agencies and donors satisfied, not something for citizens to take seriously. In many high-income countries, the situation has not been much better. National leaders and governments have signed up to UN agreements to increase aid, reduce debt, make trade fairer and reduce global warming. They have then walked away from these commitments and little or no demands for accountability have been made by citizens.

\section{Conclusion: do we need a new idea?}

Three main lessons can be drawn from this account of MDG history. First, while the idea of human development made great progress over the 1990s, this was the result of shifting networks and coalitions of actors and did not produce a robust institutional support for the promotion of the idea. Human development did well but it fell between two stools. It did not lead to the emergence of a self-fuelling social movement that could consistently place human development on the political agenda when decisions were being taken. ${ }^{16}$ The closest it came to this was with time-limited campaigns mounted by coalitions of NGOs and faith-based organisations such as Jubilee 2000, Make Poverty History and ONE. Nor did it stimulate the emergence of an elite epistemic community (in academia, the professions and the media) that was agreed on a narrowly defined analytical framework and that could dominate decisionmaking in key organisations, as had the neoliberal epistemic community in the IMF, World Bank, US Treasury and ministries of finance around the world. ${ }^{17}$ Those who wish to see the idea of human development genuinely shape policies and resource allocations post-2015 may need to put less time and effort into refining the minutiae of the concept and more time and effort into how to institutionalise the idea more fully. Could human development be honed down and politicised in a way that would foster the emergence of a social movement? Alternatively, could the idea's leading proponents chart a route 
for the creation of a tight-knit epistemic community that might wrest control of technical advice on public policy in the most powerful organisations away from neo-classical economists with a neoliberal orientation ${ }^{18}$

A second lesson is that if the post-2015 agenda pursues a global goal-setting approach, then the mechanisms by which these relate to national policies and politics in poorer countries - plans, budget allocations, medium-term expenditure frameworks, activities, approval and accountability - must be reformed. In the last decade this linkage has occurred through national PRSs that have been tightly overseen by the IMF and World Bank, and have made the notion of 'country ownership' a joke in developing countries (Hulme 2010a). As soon as possible, and definitely after 2015, the design of such mechanisms needs to shift authority and responsibility for such plans genuinely to country governments. A corresponding cultural change will be needed at the Bretton Woods Institutions, especially the IMF. They will need to adopt 'Arrogance Reduction Strategies' and learn not to believe that they know precisely what are the best policies for each specific country. The redesign of the ways in which global goals, national goals, national plans and budgets interact should remove the present-day 'misunderstanding' about whether global goals have to be monitored (and by inference met) at country level. This will provide opportunities to strengthen accountability. A similar process is needed in rich countries where citizens must be encouraged to ask, 'why do we let our politicians make big promises about global poverty reduction and let them walk away from these promises?'.

Finally, those pushing for pro-poor policies will need to distinguish between the dramatic changes in the context for development between 2000 and 2010 (or 2015) and the lack of change in the 'rules of the game' that determine global public policies and actions. The context has changed dramatically: markets are more volatile and reconfiguring with the rise of China and India; populations are ageing; climate change is under way; technological advance continues at unprecedented rates; and patterns of global governance are shifting as the G8 morphs towards a G20 (Sumner and Tiwari 2009). But the rules of the game have not changed: countries that are more economically and militarily powerful, and business interests will continue to play a dominant role in determining global public policies and in setting the limits of the degree to which these policies are actioned (or not actioned). Proponents of poverty eradication can tackle this directly by protests about aid, trade and debt. But in the long term, it will be more subtle strategies that will engineer pro-poor global policies and actions. What are needed are strategies to shift international norms so that the citizens of the present rich countries (North America, Europe and other OECD countries) and future rich countries (China, India, Brazil and others) find the existence of extreme poverty in an affluent world morally unacceptable (see Fukuda-Parr and Hulme 2009 for an elaboration). Such a shift would generate social forces that can moderate and even confront the interests of powerful countries and corporations, as happened with the slave trade and other norms (Finnemore and Sikkink 1998). This would be an incrementalist process and would need a wellarticulated idea behind it to capture the public imagination. Perhaps the biggest question for the post-2015 poverty eradication agenda is 'what is that idea?'. Is it human development à la the MDGs; or is it a revised and repackaged version of human development (promoting human rights or reducing global inequality); or, has human development passed its 'sell-by' date ... do we need a new idea?

Fukuda-Parr and Shiva Kumar (2003), ul Haq (1995), Nussbaum (2000) and Qizilbash (2006), inter alia.

3 See Locke and Latham (1990) and Heinrich (2002) for reviews. Results-based management is a sub-field of a wider and more theorised body of work, new public management (Minogue et al. 1998). 
4 For more details, see Hulme (2010a and 2010b forthcoming).

5 For a detailed history of the MDGs, see Hulme (2009a).

6 A noticeable absentee was President Clinton. US reticence about the UN's social development agenda was not confined to Republican constituencies.

7 There are only six bullet points as maternal and child mortality reduction were merged into one.

8 Annan was subjected to vitriolic attacks by a number of NGOs for sharing a common set of goals with the IMF and World Bank.

9 The MDGs were significantly modified after the 2005 Summit to include two new targets, 'reproductive health' and 'decent work', and 12 new indicators.

10 As late as 26 August 2005, the US Ambassador to the UN, John Bolton, wrote to his peers: the 'United States supports the development goals of the Millennium Declaration ... [but the] "Millennium Development Goals" ... are a [UN] Secretariat product, which member states never formally ratified'.

11 At the Monterrey meeting, he staggered his critics and supporters by announcing that 'the core development' budget would increase by 50 per cent over the next three years.

12 At the time that the MDGs were being agreed, there were several lists of human

\section{References}

Alkire, S. (2002) Valuing Freedoms: Sen's Capability Approach and Poverty Reduction, Oxford: Oxford University Press

Annan, K.A. (2001) Road Map Towards the Implementation of the United Nations Millennium Declaration, UN General Assembly, Document A/56/326, New York: United Nations

Annan, K.A. (2000) We the Peoples: The Role of the United Nations in the 21st Century, New York: United Nations Department of Public Information

Binnendijk, A. (2001) Results Based Management in the Development Cooperation Agencies: A Review of Experience, Paris: DAC Working Party on Aid Evaluation

Bradford, C. (2002) 'Towards 2015: From Consensus Formation to Implementation of the MDGs - the Historical Background, 1990-2002', mimeo, Washington DG: The Brookings Institute development goals (Alkire 2002; Clark 2002), but I can find no record of any attempt to use such specifications to shape the MDGs.

13 The G77 is the association of the UN's developing countries. It now has a membership of 130 countries, many of which have achieved middle-income status.

14 Respectively, the Canadian International Development Agency, UK's Department for International Development, Deutsche Gesellschaft für Technische Zusammenarbeit (German Technical Cooperation), Norwegian Agency for Development Cooperation, United Nations Children's Fund and United States Agency for International Development.

15 Exceptions include Brazil and Chile where parties have had to compete over poverty reduction policies, and the UK, where policy towards global poverty reduction is seen as an issue, although not a leading issue, for voters.

16 See Hulme (2010a forthcoming) for an analysis of why a social movement did not emerge.

17 Whether the Human Development and Capabilities Association (HDCA) formed in 2004 can shape its membership into an epistemic community remains to be seen.

18 In the USA this is sometimes presented as the 'saltwater economists' (New England and California) and displacing the 'freshwater economists' of Chicago.

Clark, D. (2002) Visions of Development: A Study of Human Values, Cheltenham: Edward Elgar

DAC (Development Assistance Committee) (1996) Shaping the 21st Century: The Contribution of Development Cooperation, Paris: Organisation for Economic Co-operation and Development (OECD)

Eyben, R. (2006) 'The Road Not Taken: International Aid's Choice of Copenhagen Over Beijing', Third World Quarterly 27.4: 595-608

Finnemore, Martha and Sikkink, Kathryn (1998) 'International Norm Dynamics and Political Change', International Organization 52.4: 887-917

Fukuda-Parr, S. (2006) 'Millennium Development Goal 8: Indicators for International Human Rights Obligations?', Human Rights Quarterly 28.4: 966-97

Fukuda-Parr, S. and Hulme, D. (2009) International Norm Dynamics and 'The End of Poverty': Understanding the Millennium Development 
Goals (MDGs), BWPI Working Paper 96, Manchester: University of Manchester Fukuda-Parr, S. and Shiva Kumar, A.K. (2003) Readings in Human Development: Concepts, Measures and Policies for a Development Paradigm, New Delhi and Oxford: Oxford University Press Galbraith, J.K. (1979) The Nature of Mass Poverty, Cambridge MA: Harvard University Press

ul Haq, M. (1995) Reflections on Human Development, Oxford: Oxford University Press

Heinrich, C.J. (2002) 'Outcomes-Based Performance Management in the Public Sector: Implications for Government Accountability and Effectiveness', Public Administration Review 62.6: 712-25

Hulme, D. (2010a forthcoming) Global Poverty, London: Routledge

Hulme, D. (2010b forthcoming) 'Governing Global Poverty? Global Ambivalence and the Millennium Development Goals', in J. Clapp and R. Wilkinson (eds), Global Governance, Poverty and Inequality, London: Routledge

Hulme, D. (2009a) Global Poverty Reduction and the Millennium Development Goals: A Short History of the World's Biggest Promise, Brooks World Poverty Institute Working Paper 100, Manchester: University of Manchester

Hulme, D. (2009b) Politics, Ethics and the Millennium Development Goals: The Case of Reproductive Health, Brooks World Poverty Institute Working Paper, Manchester: University of Manchester

Hulme, D. (2007) The Making of the Millennium Development Goals: Human Development Meets Results-Based Management in an Imperfect World, BWPI Working Paper 16, Manchester: University of Manchester

IMF, OECD, UN and World Bank (2000) A Better World for All, Washington DC: International Monetary Fund, Organisation for Economic Co-operation and Development, United Nations and World Bank

Jolly, R. (2003) Global Goals - The UN Experience, Background Paper for Human Development Report 2003, New York: United Nations Development Programme (UNDP)

Locke, E.A. and Latham, G.P. (1990) A Theory of Goal Setting and Task Performance, London: Prentice-Hall
Mallaby, S. (2004) The World's Banker: Story of Failed States, Financial Crises, and the Wealth and Poverty of Nations, New York: Penguin Press

Minogue, M.; Polidano, C. and Hulme, D. (1998) Beyond the New Public Management: Changing Ideas and Practices in Governance, Cheltenham: Edward Elgar

Myrdal, G. (1970) The Challenge of World Poverty: A World Anti-Poverty Program in Outline, London: Penguin

Nussbaum, M.C. (2000) Women and Human Development: The Capabilities Approach, Cambridge: Cambridge University Press

Osborne, D. and Gaebler, T. (1992) Reinventing Government: How the Entrepreneurial Spirit is Transforming the Public Sector, New York: Plume

Qizilbash, M. (2006) 'Human Development', in D. Clark (ed.), The Elgar Companion to Development Studies, Cheltenham: Edward Elgar: 245-50

Sen, A.K. (1999) Development as Freedom, New York: Knopf

Streeten, P., with Burki, S.J.; ul Haq, M.; Hicks, N. and Stewart, F. (1981) First Things First: Meeting Basic Human Needs in Developing Countries, Oxford: Oxford University Press

Sumner, A. and Tiwari, M. (2009) After 2015: International Development at the Crossroads, London: Palgrave

Thérien, J.-P. (1999) 'Beyond the North-South Divide: The Two Tales of World Poverty', Third World Quarterly 20.4: 723-42

Traub, J. (2006) The Best Intentions: Kofi Annan and the UN in the Era of American World Power, London: Bloomsbury

UN Millennium Project (2005) Investing in Development: A Practical Plan to Achieve the Millennium Development Goals, London: Earthscan

UNDP (1997) Human Development Report 1997: Human Development to Eradicate Poverty, Oxford: Oxford University Press

Vandemoortele, J. (2007) 'The MDGs: "M" for Misunderstood?', WIDER Angle 1: 6-7 